\title{
Analisis Permasalahan Pembelajaran di Masa Pandemi di SMA Negeri 1 Panai Tengah
}

\author{
Riska Melina" ${ }^{* 1}$, Riska Yanti Hasibuan ${ }^{2}$, Putri Tri Armita ${ }^{3}$, Nidaul Hasanah ${ }^{4}$, Aisyah Nur \\ Alasindo $^{5}$, Yusrizal ${ }^{6}$ \\ 1,2,3,4,5,6Bimbingan Penyuluhan Islam, Fakultas Dakwah dan Komunikasi, Universitas Islam Negeri \\ Sumatera Utara, Indonesia \\ Email: ${ }^{1}$ riskamelina2906@gmail.com, ${ }^{2}$ riskayantihasibuan14@gmail.com, \\ ${ }^{3}$ nidanasution2000@gmail.com, ${ }^{4}$ putriarmita09@gmail.com, ${ }^{5}$ aisyahnuralasindo12@gmail.com, \\ 6rizalyus405@gmail.com
}

\begin{abstract}
Abstrak
Pembelajaran dimasa pandemi membuat banyak siswa hingga mahasiswa merasa kurang mendapatkan hasil belajar yang maksimal. Dikarenakan pembelajaran online dianggap kurang maksimal dan banyak faktor-faktor yang kurang mendukung lainnya. Tujuan dari penelitian ini adalah untuk mengetahui permasalahan belajar pada siswa di SMA Negeri 1 Panai Tengah dimasa pandemi ini. Penelitian ini menggunakan metode penelitian kualitatif dan studi lapangan. Adapun hasil dari penelitian ini mengungkapkan bahwa permasalahan pembelajaran siswa disebabkan oleh faktor internal (dari dalam diri siswa) dan juga faktor eksternal (dari luar diri siswa). Yang menjadi faktor internal yaitu: minat, motivasi, perhatian, dalam belajar. Faktor eksternal yang berasal dari semua situasi dan kondisi lingkungan yang ada di sekitar siswa yang tidak mendukung aktivitas belajar siswa secara online dimasa pandemi COVID-19 meliputi jaringan yang lambat dan kuota internet yang mahal.
\end{abstract}

Kata kunci: Analisis, Pandemi, Permasalahan

\section{Abstract}

Learning during the pandemic makes many students feel that they do not get maximum learning outcomes. Because online learning is considered less than optimal and there are many other less supportive factors. The purpose of this study was to find out the learning problems of students at SMA Negeri 1 Panai Tengah during this pandemic. This research uses qualitative research methods and field studies. The results of this study revealed that students' learning problems were caused by internal factors (from within students) and also external factors (from outside students). The internal factors are: interest, motivation, attention, in learning. External factors that come from all situations and environmental conditions around students that do not support online student learning activities during the COVID-19 pandemic include slow networks and expensive internet quotas.

Keywords: Analysis, Pandemic, Problemsc

\section{PENDAHULUAN}

Menurut Kemdikbud RI menyatakan bahwa menteri pendidikan mengeluarkan surat edaran Nomor 3 Tahun 2020 tentang pencegahan corona virus disease (COVID-19) pada satuan pendidikan yang menyatakan bahwa meliburkan sekolah dan perguruan tinggi. Hal ini dilakukan untuk memutus rantai penyebaran COVID-19, sebagai gantinya kegiatan pembelajaran dilakukan secara online untuk semua jenjang pendidikan (Putri, 2021). Sistem jarak jauh menjadi salah satu solusi untuk mengatasi kesulitan dalam pembelajaran secara langsung dengan adanya aturan social distancing mengingat permasalahan waktu, lokasi, jarak dan biaya yang menjadi kendala besar saat ini (X, 2021).

Adapun faktor kesulitan belajar siswa dapat kita lihat pasca wabah pandemi COVID-19 yang mengharuskan kegiatan pembelajaran online melalui via WhatsApp group ini dilakukan untuk mengganti kegiatan pembelajaran secara langsung yakni ketika pada saat guru memberikan soal maupun materi masih banyak siswa yang pasif sehingga diskusi menjadi kurang maksimal, sering terjadi gangguan jaringan pada penggunaan WhatsApp, dan bagi siswa yang kurang aktif pada saat diskusi 
dimedia WhatsApp group juga mengalami kesulitan karena banyak ketertinggalan materi pembelajaran terutama bagi siswa yang cenderung memiliki pemahaman rendah sehingga hal-hal tersebut dapat mempengaruhi kesulitan belajar siswa (X, 2021).

Ada beberapa faktor yang mempengaruhi kesulitan pembelajaran jarak jauh di masa pandemi. Yaitu diantaranya: guru/murid gaptek, rasa malas dan sulit berkonsentrasi, jaringan yang lambat, harga kuota internet yang mahal dan siswa yang bermain-main. Dengan berbagai kondisi kesulitan yang dialami peserta didik selama pembelajaran daring, maka penelitian ini bertujuan untuk menganalisis kesulitan pembelajaran daring dengan tingkatan kesulitan yang paling memicu peserta didik dalam proses pembelajaran daring. Dengan harapan penelitian ini sebagai bahan referensi untuk pendidik dalam memahami dan memperhatikan kesulitan peserta didik.

\section{METODE PENELITIAN}

Penelitian ini memfokuskan tentang analisis permasalahan pembelajaran dimasa pandemi. Penelitian ini dilakukan di SMA Negeri 1 Panai Tengah Kab. Labuhan batu, Sumatera Utara. Penelitian ini dilakukan di November 2021. Tipe penelitian ini menggunakan pendekatan kualitatif dan studi lapangan. Data yang dikumpulkan melalui observasi, wawancara dan dokumentasi Sampel dari penelitian ini diambil 3 informan terdiri dari kelas SMA kelas X, XI dan XII. Sekitar studi lapangan yaitu melakukan wawancara, yaitu proses pengumpulan data melalui tanya jawab dan diskusi kepada pihak responden dan informan dengan cara melakukan interaksi secara langsung dengan pihak-pihak yang bersangkutan mengenai permasalahan yang diangkat. Wawancara yang digunakan peneliti yaitu metode wawancara semi struktur dengan tujuan untuk lebih mendalami pertanyaan - pertanyaan yang telah peneliti buat. Sehingga informasi yang didapatkan dari peserta didik lebih komprehensif dan sesuai dengan kesulitan yang dialami.

\section{HASIL DAN PEMBAHASAN}

Dalam penelitian ini, siswa dinyatakan mengalami kesulitan belajar pada masa pandemi COVID19. Kesulitan siswa pada masa pandemi COVID-19 dengan penggunaan pembelajaran online disebabkan oleh dua faktor, yakni faktor internal dan faktor eksternal. (SISWA) Hal ini tercantum dalam pendapat Syah yang menyatakan bahwa kesulitan belajar dibagi menjadi dua faktor, yaitu faktor internal (dari dalam diri siswa) dan faktor eksternal (dari luar diri siswa).

\subsection{Faktor Internal adalah faktor dari dalam diri yang terdiri dari :}

a. Minat

Menurut pendapat Hurlock (Trygu, 2021) minat merupakan sumber motivasi yang mendorong orang untuk melakukan apa yang mereka inginkan bila mereka bebas memilih. Disimpulkan, bahwa minat dapat menjadi sumber dari motivasi bila orang tersebut dalam kondisi bebas dalam memilih segala sesuatu (Trygu, 2021).

b. Motivasi

Motivasi dapat dikatakan sebagai dorongan psikologis seseorang sehingga melakukan tindakan untuk mencapai tujuan tertentu baik secara sadar maupun tidak sadar. (Badaruddin, 2015)

c. Perhatian dalam belajar

Pentingnya perhatian dalam kegiatan belajar mengajar telah mendorong banyak ahli memberikan batasan pengertian perhatian. Berbagai pengertian perhatian telah di rumuskan, dengan redaksi yang berbeda-beda, tetapi mempunyai maksud dan tujuan yang sama. Daryanto (Mudjiono, 2002) mengungkapkan bahwa perhatian adalah kegiatan yang dilakukan seseorang dalam hubungannya dengan pemilihan rangsangan yang datang dari lingkungannya.

d. Kesiapan belajar

Kesiapan belajar yang dimaksud dua hal yang diperhatikan dalam diri, yaitu kondisi fisik dan psikis. Dimana kondisi fisik harus bebas dari gangguan penyakit, kurang gizi, dan rasa lapar. Sedangkan kondisi psikis harus steril dari gangguan konflik kejiwaan, tekanan masalah atau ketegangan emosional (Surya, 2009). 


\subsection{Faktor Eksternal adalah faktor dari luar diri, yakni: jaringan yang lambat dan kuota internet yang mahal}

Berdasarkan penelitian yang dilakukan dapat diketahui adanya kesulitan belajar yang dialami siswa pada masa pandemi COVID-19. Yang mana dapat dilihat dari beberapa faktor yakni: guru/murid gaptek, rasa malas dan sulit berkonsentrasi, jaringan yang lambat, harga kuota internet yang mahal dan siswa yang bermain-main. Berdasarkan hasil wawancara yang telah dilakukan peneliti terhadap siswa yang bernama Nia kelas X yang memiliki minat belajar yang kurang dari sebelumnya. Dengan kebutaannya dalam akses internet dia sangat kesulitan. Bahkan pernah dia meminta pertolongan pada tetangga untuk membantu dia dalam men-scan tugasnya. Dari nia ini kita belajar bahwa setiap anak tidak memiliki kemampuan dalam menggunakan teknologi terlebih lagi pada masyarakat di daerah dia tinggal. Selanjutnya hasil wawancara yang telah dilakukan peneliti terhadap siswa yang bernama indah kelas XI dinyatakan bahwa indah adalah orang yang ambisius dalam belajar. Dimana indah ini termasuk orang yang rajin dalam mengerjakan tugas tapi dengan kendala daring menyebabkan indah terganggu karena sulit berkonsentrasi akibat kondisi rumah. Indah termasuk orang yang memiliki adik yang masih kecil yang membuat dia risih jika melakukan daring karena diganggu oleh adiknya. selanjutnya hasil wawancara yang telah dilakukan peneliti terhadap siswa yang bernama Juli Kelas XII yang sudah mendekati kelulusan untuk melanjutkan perguruan tinggi yang dimana biaya untuk membeli kuota internet itu dapat ditabung malah menjadi suatu pemborosan menurutnya.

\subsection{Upaya Atau Cara Yang Dilakukan Untuk mengatasi masalah pembelajaran pada masa pandemi}

Pada saat pembelajaran jarak jauh, para siswa sulit untuk memahami beberapa materi yang diberikan oleh gurunya atau karena adanya gangguan jaringan siswa tidak dapat sepenuhnya mendapatkan materi tersebut, sehingga siswa harus mencari lebih banyak informasi mengenai materimateri yang di pelajari dari internet. Agar hambatan tersebut tidak terjadi lagi terdapat solusi dari beberapa hambatan yang terjadi pada saat pembelajaran daring:

a. Membuat media pembelajaran sistem daring yang menarik agar siswa tidak mudah bosan

b. Mencari lokasi lokasi yang strategis untuk mengatasi jaringan yang lambat

c. Melakukan les privat/belajar otodidak tentang penggunaan teknologi

d. Mengatur waktu antara bermain dan belajar

e. Mencari suasana baru agar tidak bosan jika belajar di depan layar.

\section{KESIMPULAN}

Faktor yang menjadi permasalahan pembelajaran dimasa pandemi terdiri dari dua faktor, yaitu faktor internal dan eksternal. Yang menjadi faktor internal yaitu: minat, motivasi, perhatian, dalam belajar. Faktor eksternal yang berasal dari semua situasi dan kondisi lingkungan yang ada di sekitar siswa yang tidak mendukung aktivitas belajar siswa secara online dimasa pandemi COVID-19 meliputi jaringan yang lambat dan kuota internet yang mahal.

Upaya dalam mengatasi kesulitan belajar yang dialami siswa pada masa pandemi COVID-19 di SMA Negeri1 Panai Tengah membuat media pembelajaran sistem daring yang menarik agar siswa tidak mudah bosan. Mencari lokasi-lokasi strategis untuk mengatasi jaringan yang lambat. Melakukan les privat belajar otodidak tentang penggunaan teknologi. Mengatur waktu antara bermain dan belajar. Mencari suasana baru agar tidak bosan jika belajar di depan layar.

\section{DAFTAR PUSTAKA}

Badaruddin, A. (2015). Peningkatan Motivasi Belajar Siswa Melaui Konseling Klasikal. Jakarta: CV. Abe Kreatifindo.

Mudjiono, D. \&. (2002). Belajar dan Pembelajaran. Jakarta: PT. Rineka Cipta.

Putri, U. C. (2021). ANALISIS KESULITAN BELAJAR VIA WHATSAPP SISWA KELAS X . MATEMATICS PAEDAGOGIC, 138. 
SISWA, A. K. (n.d.). Nurul Ayu Annisa, Nuraini Asriati, Agus Sugiarto. 6.

Surya, H. (2009). Menjadi Manusia Pembelajar. Jakarta: PT. Elex Media Komputindo.

Trygu. (2021). Teori Motivasi Abraham H. Maslow dan HUbungannya dengan Minat Belajar Matematika Siswa. Jakarta: Guepedia.

X, A. K. (2021). Ulty Chika Putri, Eva Margaretha Saragih, Dewi Astuti. MATEMATICS PAEDAGOGIC, 139. 